\title{
Plant extracts with potential to control of two-spotted spider mite
}

\section{Extratos vegetais com potencial de uso no controle do ácaro rajado}

\author{
Vinicius Gomes Tabet ${ }^{1}$, Marineide Rosa Vieira ${ }^{1 *}$, Gustavo Luis Mamoré Martins ${ }^{2}$, \\ Cristiane Gabas Negrão Milan de Sousa'
}

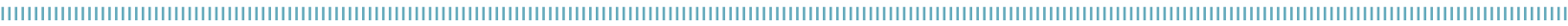

\begin{abstract}
Tetranychus urticae Koch (Acari: Tetranychidae) is a species of great economic importance to Brazil. In its control, the main option is the use of synthetic miticides, which, if used indiscriminately, can contaminate the environment, farmers and consumers. In the search for control alternatives, this study aimed to evaluate the effect of plant extracts and essential oils on females of this pest. For this, T. urticae females, reared in laboratory, were sprayed in Potter tower. Fourteen plants were tested in the form of aqueous extracts (AE), hydroethanolic extracts (HE) or essential oils (EO). The experimental plot consisted of a Petri dish with a Canavalia ensiformis L. leaf disk containing five $T$. urticae females, using ten plates per treatment. Mortality evaluations were performed 24, 48, 72, 96 and 120 hours after spraying, recording the number of dead females on the disc and the number of dead females on the moistened cotton. We considered that females found on cotton were repelled by treatments. Matricaria chamomilla L. HE and Pimpinella anisum L. AE have acaricidal effect for females, providing above $83 \%$ of mortality, after 120 hours. Origanum vulgare L. HE causes at least $75 \%$ mortality after 24 hours. Also 120 hours after spraying, $P$. anisum $\mathrm{HE}$ and $O$. vulgare $\mathrm{AE}$ cause repellency of females above $16 \%$, and $A$. absinthium HE exceeds $22 \%$ for this parameter. The results stimulate further researches to determine the optimum dose and evaluation of additional effects on the fertility of surviving females.
\end{abstract}

KEYWORDS: alternative control; Matricaria chamomilla; Origanum vulgare; Pimpinella anisum; Tetranychus urticae.
RESUMO: Tetranychus urticae Koch (Acari: Tetranychidae) é uma espécie de grande importância econômica para o Brasil. Em seu controle, a principal opção são os acaricidas sintéticos, que, se usados de forma indiscriminada, podem contaminar ambiente, produtores e consumidores. Na busca de alternativas de controle, este trabalho teve por objetivo avaliar o efeito de extratos vegetais e óleos essenciais sobre fêmeas dessa praga. Para isso, fêmeas de T. urticae criadas em laboratório foram pulverizadas em torre de Potter. Foram testadas 14 espécies vegetais, na forma de extratos aquosos (EA), hidroetanólicos $(\mathrm{EH})$ ou óleos essenciais (OE). A parcela experimental consistiu de uma placa de Petri com um disco de folha de feijão-de-porco (Canavalia ensiformis L.) contendo cinco fêmeas de T. urticae, sendo utilizadas dez placas por tratamento. As avaliaçóes de mortalidade foram realizadas 24, 48, 72, 96 e 120 horas após a pulverizaçáo, registrando-se o número de fêmeas mortas no disco e no algodão umedecido. Considerou-se que fêmeas encontradas no algodão foram repelidas pelos tratamentos. Matricaria chamomilla L. na forma de extrato hidroetanólico e Pimpinella anisum L. na forma de extrato aquoso possuem efeito acaricida para fêmeas proporcionando acima de $83 \%$ de mortalidade, após 120 horas da pulverização. Origanum vulgare L. EH causa no mínimo $75 \%$ de mortalidade após 24 horas. Também após 120 horas, P. anisum $\mathrm{EH}$ e O. vulgare EA causam repelência de fêmeas acima de $16 \%$ e A. absinthium EH ultrapassa $22 \%$ para esse parâmetro. Os resultados estimulam a realização de pesquisas futuras para determinação da dose ótima e avaliação de efeitos adicionais sobre a fertilidade das fêmeas sobreviventes.

PALAVRAS-CHAVE: controle alternativo; Matricaria chamomilla; Origanum vulgare; Pimpinella anisum; Tetranychus urticae. 


\section{INTRODUCTION}

Tetranychus urticae Koch (Acari: Tetranychidae) is a highly polyphagous mite species of great economic importance to Brazil, infesting cotton, beans, strawberry, papaya, cucumber, tomato, grape, ornamental plants, among others (MORAES; FLECHTMANN, 2008).

In this pest control, the main option is the use of synthetic acaricides, which are not always efficient, because this species has high ability to develop resistant populations (SATO et al., 2005; NICASTRO et al., 2013) and the lack of selectivity of these products to predatory mites (YAMAMOTO; BASSANEZI, 2003; REIS et al., 2006). In addition, improper use can result in environmental and food contamination, especially in the case of fruits and vegetables for fresh consumption.

The search for sustainable agriculture that enables the management of pests and diseases with less environmental damage has increased interest in the use of natural products, and there are reports in literature on mortality, decreased fertilization and disorders in the development of mites caused by them (POTENZA et al., 1999; CHOI et al., 2004; VIEIRA et al., 2006; DABROWSKI; SEREDYNSKA, 2007; PONTES et al., 2007; YANAR et al., 2011; VERONEZ et al., 2012; LABORDA et al., 2013).

Promising results have been obtained in studies using extracts and essential oils from different plant species in the control of pest mites. Thus, for T. urticae, in trials with spraying on females, Mentha spicata X suaveolens aqueous extract caused the death of $96 \%$ of females after 120 hours of application (VIEIRA et al., 2006). Essential oil of Cymbopogon citratus Boisduval in non-contact diffusion bioassay with oil application in filter paper in a closed container provided $100 \%$ mortality at a dose of $19 \times 10^{-3} \mu \mathrm{l} / \mathrm{mL}$ of air (CHOI et al., 2004). Also for this species, Stryphnodendron adstringens Mart. aqueous extract (POTENZA et al., 1999) and Artemisia absinthium L. essential oil (CHIASSON et al., 2001) provided mortality of 72 and $92 \%$, respectively. Studies on Origanum vulgare L. have shown that volatiles emanating from the essential oil have acaricide effect on T. urticae females, reaching $100 \%$ mortality as a function of concentration and exposure time (CHOI et al., 2004; ÇALMAŞUR et al., 2006). According to AFIFY (2012), Chamomilla recutita (L.) Rauschert provided 90\% mortality of $T$. urticae females when water-diluted essential oil extract was sprayed on.

Besides the lethal effect on mites, literature shows results of the effect on the fertility of mites. Bioassays carried out with $10 \%$ aqueous extracts $(\mathrm{w} / \mathrm{w})$ from different plants sprayed on $T$. urticae females evidenced reduced fertility according VERONEZ et al. (2012). These authors observed that, in control treatment the fecundity average was 5.89 eggs per female per day, being reduced for 3.72 eggs with spraying of M. spicata X suaveolens extract, 1, 1 eggs with Laurus nobilis L. extract and 0.43 eggs with Allium cepa L. extract. In tests on fumigant effect of Protium heptaphyllum (Aubl.) Marchand (Burseraceae) essential oil, a medicinal plant known as Brasil resintree, the average number of eggs per T. urticae female exposed to this oil for 24 hours decreased from 12.7 in the control treatment to 2.2 at the concentration of $4 \mu \mathrm{l}$ per liter of air (PONTES et al., 2007).

In the attempt to identify alternatives with less environmental impact for the control of T. urticae mite, this study aimed at evaluating the acaricide effect of plant extracts and essential oils on the females of this species.

\section{MATERIAL AND METHODS}

The experiment was conducted at Acarology Laboratory of São Paulo State University "Júlio de Mesquita Filho" (UNESP), School of Engineering, Ilha Solteira.

A laboratory rearing of T. urticae was developed from individuals collected in commercial vine area located in the municipality of Jales, São Paulo, Brazil (20¹6'6”S, 50³2'56”W). The mites were collected at the beginning of the experiment and kept in Petri dishes of $15 \mathrm{~cm}$ in diameter, containing a layer of cotton moistened with deionized water and leaves discs of jack bean (Canavalia ensiformis L.) of $4.2 \mathrm{~cm}$ in diameter, from plants grown in pots and kept in greenhouse. Due to plant tissue deterioration, discs were cut every four days, and the pieces containing the mites were placed on new discs.

Aqueous and hydroethanolic extracts of nine plant species and six essential oils (Table 1) were tested, as well as three control, deionized water for comparison with results of the aqueous extract, $70 \%$ alcohol for comparison with the results of the hydroethanolic extracts and abamectin (Vertimec EC $180.12 \%$ ) as chemical control.

To obtain plant extracts, the modified methodology of VIEIRA et al. (2006) was used. First, the material was washed in deionized water and kept on paper towels for 48 hours to remove excess moisture. The second step was submitting it to the stabilization process, which consisted in placing the material packed in paper bags in a forced air chamber oven at $45^{\circ} \mathrm{C}$ for 96 hours. Thereafter, the resulting dried material was submitted to grinding in a knife mill and packed in plastic bags for later obtaining aqueous and hydroethanolic extracts.

About $20 \mathrm{~g}$ were used from each of the materials previously prepared. To obtain the aqueous extract, the material was placed in a glass beaker added of $80 \mathrm{~g}$ of boil deionized water. After remaining in contact for two hours, the mixture was filtered through cotton wool, with manual pressure for extracting filtrate, packaged in amber glass and kept refrigerated at $4^{\circ} \mathrm{C}$ for up to 24 hours.

For obtaining the hydroethanolic extract, $20 \mathrm{~g}$ of material was added to $80 \mathrm{~g}$ of a $70 \%$ ethanol solution, and the 
mixture was submitted to turbo-extraction in a blender for 8 minutes, divided into two times of 4 minutes, with interval of 3 minutes. After this process, the mixture was submitted to filtration, as described for obtaining the aqueous extract.

Table 1. Plant extracts and essential oils evaluated in bioassays ${ }^{1}$ with Tetranychus urticae females.

\begin{tabular}{|c|c|c|c|}
\hline Species & $\begin{array}{l}\text { Common } \\
\text { name }\end{array}$ & $\begin{array}{l}\text { Plant } \\
\text { part } \\
\text { used }\end{array}$ & $\begin{array}{l}\text { Material } \\
\text { tested }\end{array}$ \\
\hline \multicolumn{4}{|c|}{ Experiment 1 (five treatments) } \\
\hline $\begin{array}{l}\text { Mentha spicata X } \\
\text { suaveolens }\end{array}$ & Spearmint & $\begin{array}{l}\text { Aerial } \\
\text { parts }\end{array}$ & $\mathrm{AE}$ and $\mathrm{HE}$ \\
\hline \multicolumn{4}{|c|}{ Experiment 2 (seven treatments) } \\
\hline $\begin{array}{l}\text { Lafoensia pacari } \\
\text { Saint-Hilaire }\end{array}$ & & $\begin{array}{l}\text { Aerial } \\
\text { parts }\end{array}$ & $\mathrm{AE}$ and $\mathrm{HE}$ \\
\hline Origanum vulgare L. & Oregano & Leaves & $\mathrm{AE}$ and $\mathrm{HE}$ \\
\hline \multicolumn{4}{|c|}{ Experiment 3 (seven treatments) } \\
\hline Melissa officinalis L. & $\begin{array}{l}\text { Lemon } \\
\text { balm }\end{array}$ & $\begin{array}{l}\text { Aerial } \\
\text { parts }\end{array}$ & $\mathrm{AE}$ and $\mathrm{HE}$ \\
\hline $\begin{array}{l}\text { Cymbopogon } \\
\text { citratus (D.C.) Stapf }\end{array}$ & $\begin{array}{l}\text { Lemon } \\
\text { grass }\end{array}$ & $\begin{array}{l}\text { Aerial } \\
\text { parts }\end{array}$ & $\mathrm{AE}$ and $\mathrm{HE}$ \\
\hline \multicolumn{4}{|c|}{ Experiment 4 (seven treatments) } \\
\hline $\begin{array}{l}\text { Matricaria } \\
\text { chamomilla L. }\end{array}$ & Chamomile & $\begin{array}{l}\text { Aerial } \\
\text { parts }\end{array}$ & $\mathrm{AE}$ and $\mathrm{HE}$ \\
\hline $\begin{array}{l}\text { Stryphnodendron } \\
\text { adstringens (Mart.) } \\
\text { Coville }\end{array}$ & & Bark & $\mathrm{AE}$ and $\mathrm{HE}$ \\
\hline \multicolumn{4}{|c|}{ Experiment 5 (seven treatments) } \\
\hline Pimpinella anisum $\mathrm{L}$. & Anise & $\begin{array}{l}\text { Aerial } \\
\text { parts }\end{array}$ & $\mathrm{AE}$ and $\mathrm{HE}$ \\
\hline Cinnamomum sp. & Cinnamon & $\begin{array}{l}\text { Bark and } \\
\text { leaves }\end{array}$ & EO \\
\hline $\begin{array}{l}\text { Eugenia caryophyllus } \\
\text { (Spreng.) Bullock \& } \\
\text { S. G. Harrison }\end{array}$ & Clove & Leaves & EO \\
\hline \multicolumn{4}{|c|}{ Experiment 6 (nine treatments) } \\
\hline $\begin{array}{l}\text { Artemisia } \\
\text { absinthium L. }\end{array}$ & Wormwood & $\begin{array}{l}\text { Aerial } \\
\text { parts }\end{array}$ & $\mathrm{AE}$ and $\mathrm{HE}$ \\
\hline Melissa officinalis L. & $\begin{array}{l}\text { Lemon } \\
\text { balm }\end{array}$ & $\begin{array}{l}\text { Aerial } \\
\text { parts }\end{array}$ & EO \\
\hline $\begin{array}{l}\text { Citrus limonum } \\
\text { Risso }\end{array}$ & Lemon & Fruit peel & EO \\
\hline Thymus vulgaris $\mathrm{L}$. & Thyme & $\begin{array}{l}\text { Aerial } \\
\text { parts }\end{array}$ & EO \\
\hline $\begin{array}{l}\text { Rosmarinus } \\
\text { officinalis L. }\end{array}$ & Rosemary & $\begin{array}{l}\text { Aerial } \\
\text { parts }\end{array}$ & EO \\
\hline
\end{tabular}

'In all experiments, three controls were included: deionized water, $70 \%$ alcohol and abamectin $0.12 \%$ as a chemical control. $\mathrm{AE}$ : aqueous extract; $\mathrm{HE}$ : hydroethanolic extract; EO: essential oil.
Essential oils were purchased from commercial companies: Cinnamomum sp., E. caryophyllus and T. vulgaris from Ferquima (Vargem Grande Paulista, São Paulo, Brazil); and R. officinalis, M. officinalis and C. limonum from Quinarí (Ponta Grossa, Paraná, Brazil). A dose of $10 \mathrm{~mL}$ per liter of water was used.

The experimental plot consisted of a Petri dish $(9 \mathrm{~cm}$ diameter) containing a layer of cotton wool moistened with deionized water. On this layer, one jack bean leaf disc with $3 \mathrm{~cm}$ in diameter was placed, with the lower surface up. Five T. urticae females from the rearing were transferred for each disc. Each treatment consisted of ten Petri dish.

Six experiments were carried out with a completely randomized experimental design and a variable number of treatments (Table 1). Each experiment was repeated twice to confirm the results.

Treatments were sprayed in a Potter tower with pressure of $17 \mathrm{lb} / \mathrm{in}^{2}$ and a volume of $4 \mathrm{~mL}$ per application, resulting in a deposit of $1.73 \pm 0.17 \mathrm{mg} / \mathrm{cm}^{2}$, defined based on weights of leaf discs before and after spraying with water.

Mortality evaluations were performed after 24, 48, 72, 96 and 120 hours, recording the number of dead females on the disc and the number of dead females on the moistened cotton. We considered that females found on cotton were repelled by treatments. The data were submitted to analysis of variance and means compared by Tukey test at $5 \%$ probability. Mortality and repellency percentages were corrected for mortality and repellency observed in controls treatments using Schneider-Orelli's formula (NAKANO et al., 1981).

\section{RESULTS}

Aqueous extracts (AE) of all species, except $S$. adstringens, provided T. urticae females mortalities higher than control treatment with water in both replicates, confirming the observed effect (Tables 2 and 3). However, only with P. anisum AE the corrected mortality was higher than $80 \%$ in the two replicates, being 95.2 and $83.3 \%$, with a mean of $89.2 \%$.

Values above $80 \%$ also provided by $M$. spicata X suaveolens $\mathrm{AE}, M$. officinalis $\mathrm{AE}$ and A. absinthium $\mathrm{AE}$, but in only one replicate.

The mortalities observed with hydroethanolic extracts (HE) from all species, except $M$. spicata $X$ suaveolens $\mathrm{HE}$, differed from control treatment with $70 \%$ alcohol in the both replicates. Only two species provided mortalities of T. urticae females higher than $75 \%$ with the hydroethanolic extracts obtained. The correct percentage of dead females was above this value for M. chamomilla HE, with average of $89.1 \%$ (92.5 e 85.7\%) reached after 72 horas (Fig. 1). In the case of $O$. vulgare HE, the mean mortality of $81.9 \%$ (75 and $88.9 \%$ ) was reached 
as early as 24 hours (Fig. 1). With L. pacari HE and M. offcinalis $\mathrm{HE}$, the mortalities exceeded $75 \%$ in one replicate.

Thus, the best results were obtained with $O$. vulgare HE, $M$. chamomilla $\mathrm{HE}$ and $P$. anisum AE. Low mortality was found with $C$. citratus $\mathrm{AE}$ and $M$. chamomilla $\mathrm{AE}$ and with both $S$. adstringens extracts, all below 50\%. Also, for the six essential oils tested, the mortality was low, not exceeding 30\%.

Considering the repellency effect, $P$. anisum $\mathrm{HE}$ and O. vulgare AE caused repellency of females above $16 \%$ and A. absinthium $\mathrm{HE}$ exceeds $22 \%$.

\section{DISCUSSION}

The most promising extracts for T. urticae control were $O$. vulgare $\mathrm{HE}, M$. chamomilla $\mathrm{HE}$ and $P$. anisum $\mathrm{AE}$, all with above $75 \%$ of mortality in the two replicates.

The genus Origanum (Lamiaceae) includes many species, subspecies, varieties and hybrids, being $O$. vulgare the most widely used and with the widest distribution (NAPOLI et al., 2009). Studies on the chemical composition of oregano plants have established the presence of large amounts of volatile compounds, especially carvacrol, borneol, cineol, terpineol, terpinene

Table 2. Average number of Tetranychus urticae females dead and found on the cotton, corrected percentage mortality and corrected percentage repellency, 120 hours after spraying with plant extracts. Experiments 1 to 3, two replicates (R1; R2). Ilha Solteira, São Paulo, Brazil.

\begin{tabular}{|c|c|c|c|c|c|c|c|c|}
\hline \multirow[b]{3}{*}{ Treatments } & \multicolumn{4}{|c|}{ Mortality } & \multicolumn{4}{|c|}{ Repellence } \\
\hline & \multicolumn{2}{|c|}{ R1 } & \multicolumn{2}{|c|}{ R2 } & \multicolumn{2}{|c|}{ R 1} & \multicolumn{2}{|c|}{ R2 } \\
\hline & $\begin{array}{c}\text { Dead } \\
\text { females }\end{array}$ & СРM \% & $\begin{array}{c}\text { Dead } \\
\text { females }\end{array}$ & $\begin{array}{c}\text { CPM } \\
\%\end{array}$ & $\begin{array}{c}\text { Females } \\
\text { on the } \\
\text { cotton }\end{array}$ & $\begin{array}{c}\text { CPR } \\
\%\end{array}$ & $\begin{array}{l}\text { Females } \\
\text { on the } \\
\text { cotton }\end{array}$ & $\begin{array}{c}\text { CPR } \\
\%\end{array}$ \\
\hline \multicolumn{9}{|l|}{ Experiment 1} \\
\hline Water & $1.4 \mathrm{c}$ & & $1.7 \mathrm{~b}$ & & $0.1 \mathrm{c}$ & & 0.1 & \\
\hline $70 \%$ alcohol & $1.9 \mathrm{bc}$ & & $2.4 \mathrm{~b}$ & & $0.1 \mathrm{c}$ & & 0.3 & \\
\hline M. spicata $\mathrm{X}$ suaveolens $\mathrm{AE}$ & $3.8 \mathrm{a}$ & 66.7 & $4.6 \mathrm{a}$ & 87.9 & $1.1 \mathrm{ab}$ & 20.4 & 0.4 & 6.1 \\
\hline M. spicata $\mathrm{X}$ suaveolens $\mathrm{HE}$ & $3.1 \mathrm{ab}$ & 38.7 & $4.1 \mathrm{a}$ & 64.0 & $1.9 \mathrm{a}$ & 36.7 & 0.9 & 12.8 \\
\hline Chemical control & $4.2 \mathrm{a}$ & 77.8 & $4.6 \mathrm{a}$ & 87.9 & $0.5 \mathrm{bc}$ & 8.2 & 0.3 & 4.1 \\
\hline CV (\%) & 15.5 & & 8.1 & & 19.6 & & 20.3 & \\
\hline \multicolumn{9}{|l|}{ Experiment 2} \\
\hline Water & $1.4 \mathrm{c}$ & & $0.7 \mathrm{c}$ & & 0.3 & & $0.0 \mathrm{~b}$ & \\
\hline $70 \%$ alcohol & $2.2 \mathrm{bc}$ & & $1.4 \mathrm{c}$ & & 0.3 & & $0.0 \mathrm{~b}$ & \\
\hline L. pacari $\mathrm{AE}$ & $3.8 \mathrm{a}$ & 66.7 & $3.2 \mathrm{~b}$ & 58.1 & 0.4 & 2.1 & $0.4 a b$ & 8.0 \\
\hline L. pacari HE & $3.8 \mathrm{a}$ & 57.1 & $4.7 \mathrm{a}$ & 91.7 & 0.4 & 2.1 & $0.2 \mathrm{ab}$ & 4.0 \\
\hline O. vulgare $\mathrm{AE}$ & $3.6 \mathrm{ab}$ & 61.1 & $3.9 a b$ & 74.4 & 1.1 & 17.0 & 0.8 a & 16.0 \\
\hline O. vulgare $\mathrm{HE}$ & $4.6 \mathrm{a}$ & 75.0 & $4.6 \mathrm{a}$ & 88.9 & 0.6 & 6.4 & $0.4 \mathrm{ab}$ & 8.0 \\
\hline Chemical control & $4.8 \mathrm{a}$ & 94.4 & $4.6 \mathrm{a}$ & 90.7 & 0.2 & 0.0 & $0.1 \mathrm{~b}$ & 2.0 \\
\hline CV (\%) & 14.3 & & 11.2 & & 22.8 & & 16.5 & \\
\hline \multicolumn{9}{|l|}{ Experiment 3} \\
\hline Water & $0.8 \mathrm{~d}$ & & $1.0 \mathrm{~d}$ & & $0.4 \mathrm{~b}$ & & $0.0 \mathrm{~b}$ & \\
\hline $70 \%$ alcohol & $1.4 \mathrm{~cd}$ & & $1.1 \mathrm{~cd}$ & & $0.0 \mathrm{~b}$ & & $0.1 \mathrm{ab}$ & \\
\hline M. officinalis AE & $2.9 \mathrm{~b}$ & 50.0 & $4.5 \mathrm{a}$ & 87.5 & $0.8 \mathrm{ab}$ & 8.7 & $0.0 \mathrm{~b}$ & 0.0 \\
\hline M.officinalis HE & $3.7 \mathrm{ab}$ & 63.9 & $4.2 \mathrm{a}$ & 79.5 & $1.3 \mathrm{a}$ & 26.0 & $0.5 a b$ & 8.2 \\
\hline C. citratus AE & $2.4 \mathrm{bc}$ & 38.1 & $2.2 \mathrm{bc}$ & 30.0 & $0.8 \mathrm{ab}$ & 8.7 & $0.2 a b$ & 4.0 \\
\hline C. citratus HE & $3.4 \mathrm{ab}$ & 55.6 & $3.5 a b$ & 61.5 & $1.4 \mathrm{a}$ & 28.0 & $0.6 \mathrm{a}$ & 10.2 \\
\hline Chemical control & $4.8 \mathrm{a}$ & 95.2 & $4.9 \mathrm{a}$ & 97.5 & $0.2 \mathrm{~b}$ & 0.0 & $0.1 \mathrm{ab}$ & 2.0 \\
\hline CV (\%) & 13.6 & & 13.3 & & 18.8 & & 16.4 & \\
\hline
\end{tabular}

CPM: corrected percentage mortality; CPR: corrected percentage repellency; AE: aqueous extract; HE: hydroethanolic extract; CV: coefficient of variation. Original means. Statistical analysis with data transformed into $(x+1)^{1 / 2}$. In column, for each experiment, means followed by different letters differ by Tukey test at $5 \%$ probability. 
and thymol (ŞAHIN et al., 2004; LORENZI; MATOS, 2008; NAPOLI et al., 2009). The volatiles emanating from the essential oil have acaricide effect on T. urticae females, reaching $100 \%$ mortality as a function of concentration and exposure time (CHOI et al., 2004; ÇALMAŞUR et al., 2006). In addition to this oregano species, there is record of acaricide effect of essential oil from Origanum syriacum var. bevanii (TUNÇ; ŞAHINKAYA, 1998) and Origanum onites L. (SERTKAYA et al., 2010) on T. cinnabarinus females, with mortality above $90 \%$. The high mortality due to the effect fumigant of carvacrol was recorded by TABARI et al. (2015) for Dermanyssus gallinae (De Geer) mite (Dermanyssidae). Antibacterial and

Table 3. Average number of Tetranychus urticae females dead and found on the cotton, corrected percentage mortality and corrected percentage repellency, 120 hours after spraying with plant extracts. Experiments 4 to 6, two replicates (R1; R2). Ilha Solteira, São Paulo, Brazil.

\begin{tabular}{|c|c|c|c|c|c|c|c|c|}
\hline \multirow{3}{*}{ Treatments } & \multicolumn{4}{|c|}{ Mortality } & \multicolumn{4}{|c|}{ Repellence } \\
\hline & \multicolumn{2}{|c|}{$\mathbf{R} 1$} & \multicolumn{2}{|c|}{ R2 } & \multicolumn{2}{|c|}{$\mathbf{R} 1$} & \multicolumn{2}{|c|}{$\mathbf{R 2}$} \\
\hline & $\begin{array}{c}\text { Dead } \\
\text { females }\end{array}$ & $\begin{array}{c}\text { CPM } \\
\%\end{array}$ & $\begin{array}{c}\text { Dead } \\
\text { females }\end{array}$ & $\begin{array}{c}\text { CPM } \\
\%\end{array}$ & $\begin{array}{c}\text { Females } \\
\text { on the } \\
\text { cotton }\end{array}$ & $\begin{array}{c}\text { CPR } \\
\%\end{array}$ & $\begin{array}{c}\text { Females } \\
\text { on the } \\
\text { cotton }\end{array}$ & $\begin{array}{c}\text { CPR } \\
\%\end{array}$ \\
\hline \multicolumn{9}{|l|}{ Experiment 4} \\
\hline Water & $0.6 \mathrm{e}$ & & $0.6 \mathrm{~d}$ & & $0.1 \mathrm{a}$ & & 0.0 & \\
\hline $70 \%$ alcohol & $1.0 \mathrm{de}$ & & $0.8 \mathrm{~d}$ & & $0.5 a$ & & 0.1 & \\
\hline M. chamomilla $\mathrm{AE}$ & $2.7 b c$ & 47.7 & $2.7 b c$ & 47.7 & $0.1 \mathrm{a}$ & 0.0 & 0.2 & 4.0 \\
\hline M. chamomilla $\mathrm{HE}$ & $4.7 \mathrm{a}$ & 92.5 & $4.4 a b$ & 85.7 & $0.3 \mathrm{a}$ & 0.0 & 0.4 & 6.1 \\
\hline S. adstringens $\mathrm{AE}$ & $1.6 \mathrm{~cd}$ & 22.7 & $1.5 \mathrm{~cd}$ & 20.5 & $0.7 \mathrm{a}$ & 12.2 & 0.3 & 6.0 \\
\hline S. adstringens $\mathrm{HE}$ & $3.0 \mathrm{~b}$ & 50.0 & $2.2 \mathrm{c}$ & 33.3 & $0.7 \mathrm{a}$ & 4.4 & 0.1 & 0.0 \\
\hline Chemical control & $4.9 \mathrm{a}$ & 97.7 & $4.8 \mathrm{a}$ & 95.5 & $0.1 \mathrm{a}$ & 0.0 & 0.1 & 2.0 \\
\hline CV (\%) & 13.1 & & 18.5 & & 18.0 & & 15.5 & \\
\hline \multicolumn{9}{|l|}{ Experiment 5} \\
\hline Water & $0.8 b$ & & $0.8 \mathrm{~b}$ & & $0.1 \mathrm{~b}$ & & $0.2 b c$ & \\
\hline $70 \%$ alcohol & $0.7 \mathrm{~b}$ & & $0.7 \mathrm{~b}$ & & $0.0 \mathrm{~b}$ & & $0.0 \mathrm{c}$ & \\
\hline P. anisum $\mathrm{AE}$ & $4.8 \mathrm{a}$ & 95.2 & $4.3 \mathrm{a}$ & 83.3 & $0.2 \mathrm{~b}$ & 2.0 & $0.6 a b c$ & 8.3 \\
\hline P. anisum $\mathrm{HE}$ & $3.7 \mathrm{a}$ & 69.8 & $3.6 \mathrm{a}$ & 67.4 & $0.9 \mathrm{a}$ & 18.0 & $1.3 \mathrm{a}$ & 26.0 \\
\hline C. zeylanicum EO & $0.6 \mathrm{~b}$ & 0.0 & $0.7 \mathrm{~b}$ & 0.0 & $0.1 \mathrm{~b}$ & 0.0 & $0.2 b c$ & 0.0 \\
\hline E. caryophyllus EO & $1.0 \mathrm{~b}$ & 7.0 & $1.2 \mathrm{~b}$ & 11.6 & $0.3 a b$ & 6.0 & $0.8 a b$ & 16.0 \\
\hline Chemical control & $4.6 \mathrm{a}$ & 90.5 & $4.7 \mathrm{a}$ & 92.9 & $0.2 \mathrm{~b}$ & 2.0 & $0.1 b c$ & 0.0 \\
\hline CV (\%) & 13.0 & & 14.6 & & 16.6 & & 18.0 & \\
\hline \multicolumn{9}{|l|}{ Experiment 6} \\
\hline Water & $0.4 \mathrm{c}$ & & $0.4 c$ & & $0.1 \mathrm{~b}$ & & $0.1 \mathrm{~b}$ & \\
\hline $70 \%$ alcohol & $1.1 \mathrm{bc}$ & & $1.5 b$ & & $0.0 \mathrm{~b}$ & & $0.0 \mathrm{~b}$ & \\
\hline A. absinthium $\mathrm{AE}$ & $4.5 \mathrm{a}$ & 89.1 & $3.5 \mathrm{a}$ & 67.4 & $0.4 b$ & 6.1 & $0.5 a b$ & 8.2 \\
\hline A. absinthium $\mathrm{HE}$ & $3.9 \mathrm{a}$ & 71.8 & $3.5 \mathrm{a}$ & 57.1 & $1.1 \mathrm{a}$ & 22.0 & $1.2 \mathrm{a}$ & 24.0 \\
\hline R. officinalis EO & $1.5 b$ & 23.9 & $0.9 b c$ & 10.9 & $0.2 \mathrm{~b}$ & 2.0 & $0.1 \mathrm{~b}$ & 0.0 \\
\hline M. officinalis EO & $0.9 \mathrm{bc}$ & 10.9 & $0.9 \mathrm{bc}$ & 10.9 & $0.5 a b$ & 8.2 & $0.1 \mathrm{~b}$ & 0.0 \\
\hline C. limonum EO & $1.6 \mathrm{~b}$ & 26.1 & $1.1 \mathrm{bc}$ & 15.2 & $0.1 \mathrm{~b}$ & 0.0 & $0.1 \mathrm{~b}$ & 0.0 \\
\hline T. vulgaris EO & $1.6 \mathrm{~b}$ & 26.1 & $1.0 \mathrm{bc}$ & 13.0 & $0.1 \mathrm{~b}$ & 0.0 & $0.0 \mathrm{~b}$ & 0.0 \\
\hline Chemical control & $4.2 \mathrm{a}$ & 82.6 & $4.8 \mathrm{a}$ & 95.7 & $0.4 \mathrm{~b}$ & 6.1 & $0.1 \mathrm{~b}$ & 0.0 \\
\hline CV (\%) & 15.3 & & 15.1 & & 16.0 & & 15.6 & \\
\hline
\end{tabular}

CPM: corrected percentage mortality; CPR: corrected percentage repellency; CV: coefficient of variation; AE: aqueous extract; HE: hydroethanolic extract; EO: essential oil. Original means. Statistical analysis with data transformed into $(x+1)^{1 / 2}$. In column, for each experiment, means followed by different letters differ by Tukey test at $5 \%$ probability. 
antifungal activities have also been recorded for the essential oil from O. vulgare (ŞAHIN et al., 2004).

In the case of M. chamomilla, extracts prepared with waterdiluted essential oil and addition of a surfactant, sprayed on T. urticae females provided 75 and $90 \%$ mortality at 1 and $2 \%$ concentrations, respectively. At $4 \%$, the mortality was total. With the lowest concentration, the eggs viability was reduced $45 \%$, and $70 \%$ with the $2 \%$ concentration, when extracts were sprayed on them (AFIFY, 2012). According to these authors, the main compounds of chamomile essential oil are bisabolol oxide $\mathrm{A}$ e trans- $\beta$-farnesene. Its aqueous extract can cause mortality of up to $100 \%$ of Psoroptes cuniculi Delafond mite (Psoroptidae), responsible for otoacariasis in domestic animals, as observed by MACCHIONI et al. (2004), and its essential oil has high repellent effect on Dermatophagoides farinae Hughes and Dermatophagoides pteronyssinus (Trouessart) (Acari: Pyroglyphidae) (KANG; JEE, 2012). For $P$. anisum essential oil, vapors can be lethal to T. cinnabarinus (TUNÇ; ŞAHINKAYA, 1998).

The results obtained with $O$. vulgare $\mathrm{HE}, M$. chamomilla $\mathrm{HE}$ and $P$. anisum $\mathrm{AE}$ were very consistent, with similar findings in both repetitions. However, different results were recorded for various extracts, as in the case of $L$. pacari $\mathrm{HE}$, with mortalities of 57.1 and $91.7 \%$. This variation in results is one of the difficulties found in the use of plant extracts to control pests. The composition of a plant extract depends on genetic characteristics and environmental conditions. Thus, the season in which the plant was grown, the local climate conditions, the plant age at harvest and the collection processes can affect the chemical composition of extracts and essential oils obtained (ATTIA et al., 2013).

Agricultural practices used in the cultivation may also influence such characteristics. Consequently, water availability can directly affect the synthesis of some secondary metabolites. In the group of alkaloids, when the crop is intensely irrigated, there is an increase in green matter productivity, but decrease in active ingredient content of leaves (MING,

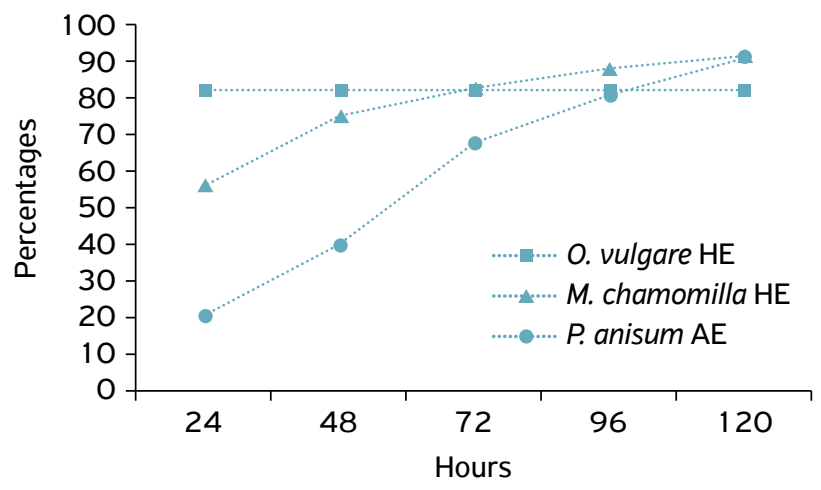

HE: hydroethanolic extract; $A E$ : aqueous extract.

Figure 1. Mortality percentages of Tetranychus urticae females sprayed with plant extracts up to 120 hours after spraying. Ilha Solteira, São Paulo, Brazil.
1994). For $P$. anisum, water stress decreased the production of essential oils (ZEHTAB-SALMASI et al., 2001). According to GERSHENZON (1984), in dry weather the essential oil of Thymus serrulatus Hochst. ex Benth. consists mainly of thymol and carvacrol, while in the rainy season it has higher amounts of linalool. This author also observed that the availability of nitrogen can affect the production of active ingredients, increasing the yield in spearmint and oregano and decreasing in lemon balm. LOBO (1976) observed that the terpene synthesis requires the presence of magnesium to form its precursor compounds. These problems could be lower with producer cultivating the plants of interest for his/her own use and standardizing some environmental conditions.

For the six essential oils, tested mortality was less than $30 \%$, all in females spraying tests. In the experiments by LABORDA et al. (2013), R. officinalis essential oil $0.2 \%$ in immersion tests with T. urticae females, trapped on microscope slides, caused 95\% mortality 1 hour after treatment. Best results have been obtained in studies about essential oils effects with fumigation tests, in which the volatile compounds present acaricide effect (ATTIA et al., 2013).

Seven extracts provided repellent effect between 16 and $36.7 \%$ in at least one replicate (Tables 2 and 3). Considering mortality and repellency, these extracts could have a greater impact on the population of T. urticae. In addition, the repellency evaluation was based on the number of females found dead on the moistened cotton surrounding leaf discs. This methodology does not allow assessing what would have happened to these individuals without this barrier. It is possible that some of these females were intoxicated and would die a few hours later, especially for extracts that showed increased mortality over time. Therefore, mortality using these extracts may have been higher. P. anisum $\mathrm{HE}$, for example, caused mortalities of 69.8 and $67.4 \%$, considering the two replicates. This extract provided 18 and $26 \%$ as repellence percentages. As a result, the mortality may have been up to 87.8 and $93.4 \%$, respectively.

The results obtained, especially in the case of $O$. vulgare HE, M. chamomilla $\mathrm{HE}$ and $P$. anisum $\mathrm{AE}$, that provided average mortality over $75 \%$, stimulate the development of more detailed studies. Further researches could include the determination of the optimal dosage and the evaluation of additional effects on biological cycle and fertility of surviving females.

T. urticae is a very important pest of many crops, including those ones that produce fruit for fresh consumption, as papaya, grape and strawberry. In its control, the possibility of using natural products, less toxic, might be very important to ensure healthier agricultural products.

In the case of hydroethanolic extracts, considering the goal of providing a viable alternative to small farmers, a possibility to be researched is to obtain the extract by soaking leaves in alcohol for a certain period of time, replacing to blender use, which could make the process easier and safer. 


\section{CONCLUSIONS}

M. chamomilla L. HE and P. anisum L. AE have acaricidal effect on T. urticae female, providing above $83 \%$ of mortality, after 120 hours. O. vulgare L. HE causes at least $75 \%$ mortality after 24 hours. Also 120 hours after spraying, $P$. anisum $\mathrm{HE}$ and $O$. vulgare $\mathrm{AE}$ cause repellency of females above $16 \%$, and $A$. absinthium HE exceeds $22 \%$ for this parameter.

The results stimulate further researches to determine the optimum dose and evaluation of additional effects on the fertility of surviving females.

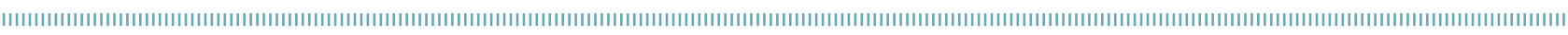
REFERENCES

AFIFY, A.E.M.M.R.; ALI, F.S.; TURKY, A.F. Control of Tetranychus urticae Koch by extracts of three essential oils of chamomile, marjoram and Eucalyptus. Asian Pacific Journal of Tropical Biomedicine, v.2, n.1, p.24-30, 2012. DOI: 10.1016/ S2221-1691(11)60184-6

ATTIA, S.; GRISSA, K.L.; LOGNAY, G.; BITUME, E.; HANCE, T.; MAILLEUX, A.C. A review of the major biological approaches to control the worldwide pest Tetranychus urticae (Acari: Tetranychidae) with special reference to natural pesticides. Journal of Pest Science, v.86, n.3, p.361-386, 2013.

ÇALMAŞUR, O.; ASLAN, I.; ŞAHIN, F. Insecticidal and acaricidal effect of three Lamiaceae plant essential oils against Tetranychus urticae Koch and Bemisia tabaci Genn. Industrial Crops and Products, v.23, n.2, p.140-146, 2006. DOI: 10.1016/j. indcrop.2005.05.003

CHIASSON, H.; BÉLANGER, A.; BOSTANIAN, N; VINCENT, C.; POLIQUIN, A. Acaricidal properties of Artemisia absinthium and Tanacetum vulgare (Asteraceae) essential oils obtained by three methods of extraction. Journal of Economic Entomology, v.94, n. 1, p.167-171, 2001. DOI: 10.1603/0022-0493-94.1.167

CHOI, W.I.; LEE, S.G.; PARK, H.M.; AHN, Y.J. Toxicity of plant essential oils to Tetranychus urticae (Acari: Tetranychidae) and Phytoseiulus persimilis (Acari: Phytoseiidae). Journal of Economic Entomology, v.97, n.2, p.553-558, 2004. DOI: 10.1603/0022-0493-97.2.553

DABROWSKI, Z.T.; SEREDYNSKA, U. Characterisation of the twospotted spider mite (Tetranychus urticae Koch, Acari: Tetranychidae) response to aqueous extracts from selected plant species. Journal of Plant Protection Research, v.47, n.2, p.113-124, 2007.

GERSHENZON, J. Changes in the levels of plant secondary metabolites under water and nutrient stress. Recent Advances in Phytochemistry, v.18, n.2, p.273-320, 1984. DOI: 10.1007/978-1-4684-1206-2_10

KANG, M.G.; JEE, C.H.. Repellent effect of camomile and lavender essential oils against house dust mite in bed fabric. Journal of Biomedical Research, v.13, n.1, p.21-26, 2012.

LABORDA, R.; MANZANO, I.; GAMÓN, M.; GAVIDIA, I.; PÉREZBERMÚDEZ, P.; BOLUDA, R. Effects of Rosmarinus officinalis and Salvia officinalis essential oils on Tetranychus urticae Koch (Acari: Tetranychidae). Industrial Crops and Products, v.48, n.1, p.106-1 10, 2013. DOI: 10.1016/j.indcrop.2013.04.011
LOBO, A.M. Biossíntese de produtos naturais - metabolismo secundário. Lisboa: Universidade Nova de Lisboa, 1976. 201 p.

LORENZI, H.; MATOS, F.J.A. Plantas medicinais no Brasil: nativas e exóticas. 2. ed. Nova Odessa: Instituto Plantarum, 2008. 544p.

MACCHIONI, F.; PERRUCCI, S.; CECCHI, F.; CIONI, P.L.; MORELLI, I.; PAMPIGLIONE, S. Acaricidal activity of aqueous extracts of chamomile flowers, Matricaria chamomilla, against the mite Psoroptes cuniculi. Medical and Veterinary Entomology, v. 18, n.2, p.205-207, 2004. DOI: $10.1111 /$ j.0269-283X.2004.00488.x

MING, L.C. Estudo e pesquisa de plantas medicinais na Agronomia. Horticultura Brasileira, v.12, n. 1, p.3-9, 1994.

MORAES, G.J.; FLECHTMANN, C.H.W. Manual de Acarologia: acarologia básica e ácaros de plantas cultivadas no Brasil. Ribeirão Preto: Holos, 2008. 308p.

NAKANO, O.; SILVEIRA NETO, S.; ZUCCHI, R.A. Entomologia econômica. São Paulo: Ceres, 1981. 314 p.

NAPOLI, E.M.; CURCURUTO, G.; RUBERTO, G. Screening the essential oil composition of wild Sicilian oregano. Biochemical Systematics and Ecology, v.37, n.4, p.484-493, 2009. DOI: 10.1016/j. bse.2009.07.008

NICASTRO, R.L.; SATO, M.E.; ARTHUR, V.; SILVA, M.Z. Chlorfenapyr resistance in the spider mite Tetranychus urticae: stability, cross-resistance and monitoring of resistance. Phytoparasitica, v.41, n.5, p.503-513, 2013. DOI: 10.1007/ s12600-013-0309-x

PONTES, W.J.T.; OLIVEIRA, J.C.G.; CÂMARA, C.A.G.; LOPES, A.C.H.R.; GONDIM JÚNIOR, M.G.C.; OLIVEIRA, J.V.; BARROS, R.; SCHWARTZ, M.O.E. Chemical composition and acaricidal activity of the leaf and fruit essential oils of Protium heptaphyllum (Aubl.) Marchand (Burseraceae). Acta Amazonica, v.37, n.1, p.103-109, 2007. DOI: /10.1590/ S0044-59672007000100012

POTENZA, M.R.; TAKEMATSU, A.P.; BENEDICTO, L.H. Avaliação do controle de Tetranychus urticae (Koch, 1836) (Acari: Tetranychidae) através de extratos vegetais, em laboratório. Arquivos do Instituto Biológico, v.66, n.2, p.91-97, 1999.

REIS, P.R.; FRANCO, R.A.; PEDRO NETO, M.; TEODORO, A.V. Selectivity of agrochemical son predatory mites (Phytoseiidae) found on coffee plants. Coffee Science, v. 1, n. 1, p.64-70, 2006. 
ŞAHIN, F.; GÜLLÜCE, M.; DAFERERA D.; SOKMEN, A.; SÖKMEN, M.; POLISSIOU, M.; AGAR, G.; OZER, H. Biological activities of the essential oils and methanol extract of Origanum vulgare ssp. vulgare in the Eastern Anatolia region of Turkey. Food Control, v. 15, n.7, p.549-557, 2004. DOI: 10.1016/j.foodcont.2003.08.009

SATO, M.E.; SILVA, M.Z.; RAGA, A.; SOUZA FILHO, M.F. Abamectin resistance in Tetranychus urticae Koch (Acari: Tetranychidae): Selection, cross-resistance and stability of resistance. Neotropical Entomology, v.34, n.6, p. 1-8, 2005. DOI: 10.1590/S1519-566X2005000600016

SERTKAYA, E.; KAYA, K.; SOYLU, S. Acaricidal activities of the essential oils from several medicinal plants against the carmine spider mite (Tetranychus cinnabarinus Boisd.) (Acarina: Tetranychidae). Industrial Crops and Products, v.31, n. 1, p.107-112, 2010. DOI: 10.1016/j.indcrop.2009.09.009

TABARI, M. A.; YOUSSEFI, M. R.; BARIMANI, A.; ARAGHI, A. Carvacrol as a potent natural acaricide against Dermanyssus gallinae. Parasitology Research, v.1 14, n.10, p.3801-3806, 2015. DOI: $10.1007 / \mathrm{s} 00436-015-4610-0$

TUNÇ, I.; ŞAHINKAYA, S. Sensitivity of two greenhouse pests to vapours of essential oils. Entomologia Experimentalis et Applicata, v.86, n.2, p.183-187, 1998. dOI: 10.1023/A:1003193729634
VERONEZ, B.; SATO, M.E.; NICASTRO, R.L. Toxicidade de compostos sintéticos e naturais sobre Tetranychus urticae e o predador Phytoseiulus macropilis. Pesquisa Agropecuária Brasileira, v.47, n.4, p.511-518, 2012. DOI: 10.1590/ s0100-204X2012000400006.

VIEIRA, M.R.; SACRAMENTO, L.V.S.; FURLAN, L.O.; FIGUEIRA, J.C.; ROCHA, A.B.O. Efeito acaricida de extratos vegetais sobre fêmeas de Tetranychus urticae Koch (Acari: Tetranychidae). Revista Brasileira de Plantas Medicinais, v.8, n.4, p.210-217, 2006.

YAMAMOTO, P.T.; BASSANEZI, R.B. Seletividade de produtos fitossanitários aos inimigos naturais de pragas dos citros. Laranja, v.24, n.2, p.353-382, 2003.

YANAR, D.; KADIOǦLU, I.; GÖKÇE, A. Acaricidal effects of different plant parts extracts on two-spotted spider mite (Tetranychus urticae Koch). African Journal of Biotechnology, v. 10, n.55, p. $11745-11750,2011$.

ZEHTAB-SALMASI, S.; JAVANSHIR, A.; OMIDBAIGI, R.; ALYARI, H.; GHASSEMI-GOLEZANI, K. Effects of water supply and sowing date on performance and essential oil production of anise (Pimpinella anisum L.). Acta Agronomica Hungarica, v.49, n. 1, p.75-81, 2001. DOI: 10.1556/AAgr.49.2001.1.9 